\title{
Crossrail project: the execution strategy for delivering London"s Elizabeth line
}

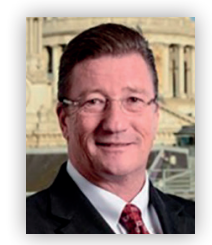

William Tucker BSArch, MArch

Principal Vice President, Bechtel Ltd, London, UK; Central Section Delivery

Director, Crossrail Ltd, London, UK

\begin{abstract}
Crossrail, the project to deliver the Elizabeth line east-west railway across London, is the largest construction project in Europe. The Crossrail Act 2008 outlined the principles of an execution strategy for delivery of the 10 year programme, which will see the new line fully operational in 2019. At the heart of the strategy was a vision for how the railway would be delivered through best practice and responsible procurement, via a project delivery partner, a programme partner, designers and contractors as well as development agreements with key stakeholders. From 2008 through completion of tunnelling in 2015 and into systems and architectural finishing works, this vision has remained constant. This paper outlines the execution strategy and how it came to remain intact as a basis of delivery throughout the life of the project.
\end{abstract}

\section{Introduction}

Crossrail, the project to deliver the Elizabeth line east-west railway across London, is the largest construction project in Europe. Initial services will start running in 2018 and the line will be fully open by the end of 2019 .

After a long history of development and planning dating back to 1974 , a bill was submitted to the UK parliament in 2005 and received royal assent in 2008 as the Crossrail Act 2008. This Act of Parliament gave the powers necessary to build the line and for the Secretary of State to nominate Crossrail Ltd. as the undertaker for the project. The bill, which was the output of years of work, was accompanied by a number of documents that outlined the principles of an execution strategy for delivery of the programme.

Crossrail developed a vision for how the railway would be delivered through best practice and responsible procurement. This vision became embedded into procurement strategies that retained the services of a project delivery partner, a programme partner, designers and contractors. The vision was also embedded into development agreements with key stakeholders that would contribute to the scheme, including London Underground, Network Rail, Canary Wharf Group and Berkeley Homes.

From 2008 through completion of tunnelling in 2015 and into systems and architectural finishing works, this vision has remained constant. This paper outlines that execution strategy and how it came to remain intact as a basis of Crossrail's delivery throughout the life of the project.

\section{Foundations}

Crossrail is constructing a $118 \mathrm{~km}$ railway line that stretches across London and its environs from Reading in Berkshire and Heathrow airport in the London Borough of Hillingdon in the west, to Shenfield in Essex in the north-east and Abbey Wood in the London Borough of Greenwich in the south-east (Figure 1).

The new line, to be named the Elizabeth line when it opens through central London in 2018, is designed to increase the capacity of central London's rail transportation network by $10 \%$, relieving congestion at a number of existing London Underground stations and at two key Network Rail stations, Paddington and Liverpool Street. Nine-carriage trains $200 \mathrm{~m}$ long will run at frequencies up to 24 trains per hour through central London.

The central section, which comprises $21 \mathrm{~km}$ of twin-bore tunnels, will include nine new stations in the tunnelled section of the route, five portals and five intermediate shafts in addition to a tenth new station at Abbey Wood. New depot and maintenance facilities are being constructed at Ilford, Plumstead and Old Oak Common.

The authorities and funding for the project were granted by parliament in 2008 through the Crossrail Act and an agreement with the project's joint sponsors, Transport for London (TfL) and the Department for Transport (DfT). The key elements of the project's $£ 14.8$ billion funding package are as follows.

- The mayor of London, through TfL and the Greater London Authority (GLA), contributed $£ 7 \cdot 1$ billion, including a direct contribution from TfL of $£ 1.9$ billion and contributions raised through the Crossrail business rate supplement and the community infrastructure levy.

- Fare payers will contribute towards the debt raised by TfL during construction.

- The government contributed by means of a grant from the DfT of $£ 4.7$ billion during Crossrail's construction. London businesses have contributed $£ 4 \cdot 1$ billion through a variety of mechanisms, including the business rate supplement.

- Network Rail is undertaking the on-network works costing no more than $£ 2.3$ billion, which will be recouped from track 


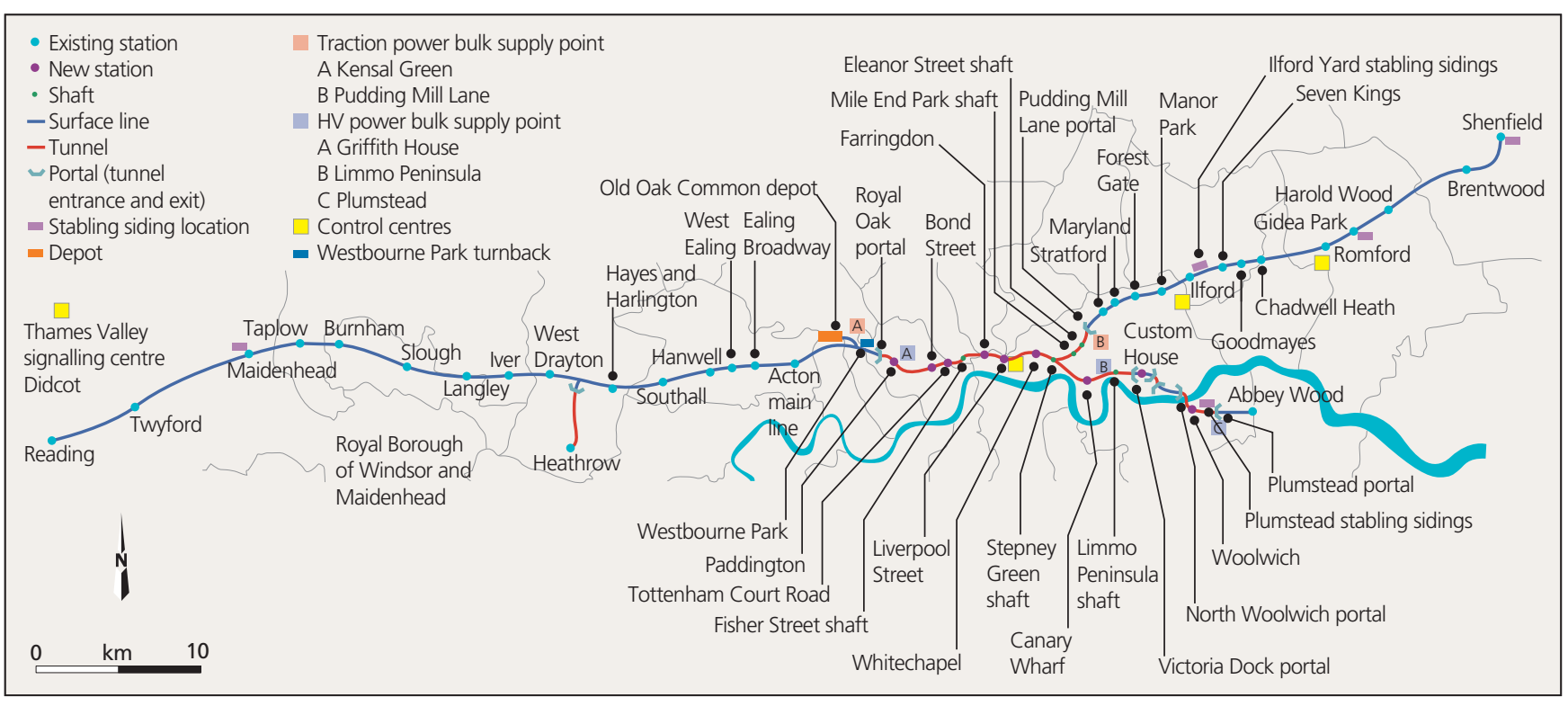

Figure 1. The Elizabeth line across London will officially open when trains start running through the central Paddington to Liverpool Street section in December 2018

access charges paid through projected operating surpluses from the operation of Elizabeth line services.

- Additional financial contributions have been made by some of the key beneficiaries of the Crossrail scheme, including the City of London Corporation, Heathrow Airport Holdings Ltd, Canary Wharf Group and Berkeley Homes.

The $£ 14.8$ billion funding envelope for the project is a fully inclusive cost, allowing for both contingency and inflation. Over $60 \%$ of the funding comes from Londoners and London businesses.

There was an extraordinary level of investigation, planning, design and thought that needed to go into the development of the scheme and how it would be built, to a point of specificity that allowed a firm plan and cost proposal to be submitted with the bill to secure both the powers and funding to construct such a massive project.

Key among the outputs at this time were an environmental impact assessment, the Crossrail construction code and a series of information papers that addressed key commitments on a delivery strategy and important risks to the project. These included underground construction, sprayed concrete lining, control of construction traffic, land and property acquisition and community relations, and an execution strategy.

In addition, a project development agreement was issued by the joint sponsors that communicated to Crossrail the sponsor's requirements that needed to be satisfied in the delivery of the scheme. Crossrail's execution plan was therefore developed to implement these key inputs. It revolved around the engagement of two strategic partners - the project delivery partner and programme partner - which would assist Crossrail in delivering the project alongside the various consultants and contractors that would design and build the scheme.

\section{Crossrail's vision and values}

From the outset, Crossrail intended to do more than simply build a reliable and architecturally significant railway that would increase London's rail network capacity and performance. A statement of principles was issued, stating that the government and the mayor believed the scheme would create the transport infrastructure needed to support the economic growth of London and its regeneration areas, facilitate its continued development as a world city and sustain its position as the financial centre of Europe.

A vision statement that represented the ultimate outcome for the project was agreed by the Crossrail board in 2006: 'A world class, affordable railway delivered through effective partnerships and project excellence'.

An internal document entitled Delivering Crossrail Through Best Practice and Responsible Procurement was published in December 2007 to further articulate how Crossrail would accomplish its vision. This document summarised the sponsorship and ownership for delivery of the project, how the project would be governed, the basic programme and strategy for construction of the tunnelled section of the route (Figure 2) and how the project would be organised for delivery. Key principles of how the project would be delivered, including procurement and technical assurance, were set out. These principles were translated into the briefing material that formed part of the tender requirements for the project delivery and programme partner contracts.

In 2012, Crossrail refined the articulation of its vision into the simple phrase 'Moving London forward'. Its mission of delivering a world-class railway that fast-tracks the progress of London brought together hundreds of different organisations and thousands of individuals around a common goal and a set of values that represent what was important to Crossrail - safety, inspiration, respect, collaboration and integrity. These values have driven the 
Civil Engineering

Volume 170 Issue CE5
Crossrail project: the execution strategy for delivering London's Elizabeth line

Tucker

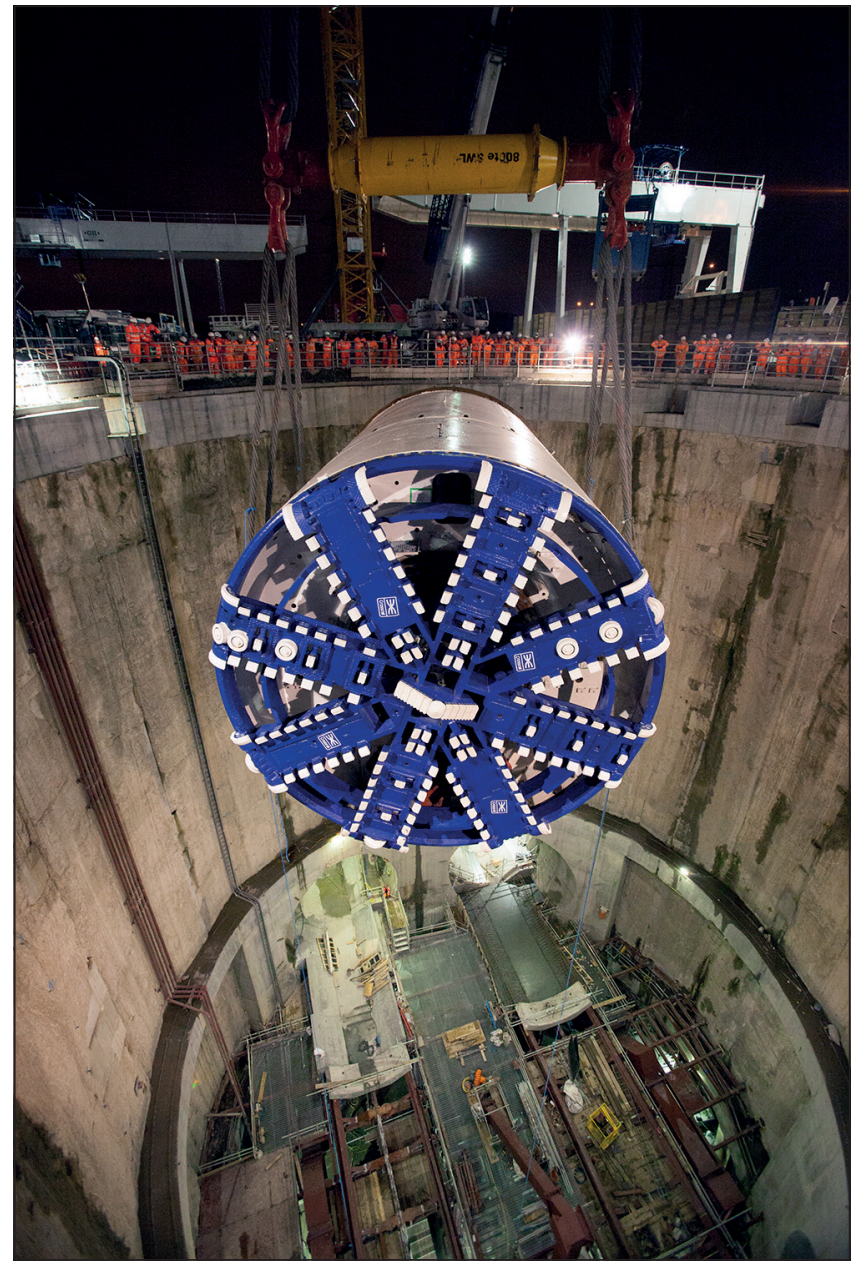

Figure 2. Tunnel boring machine being lowered at Limmo Peninsula the strategy for safe delivery of the tunnelled section was set out in 2007

behaviours necessary to achieve the project's objectives: to be safe, on time, within funding and world class.

Safety has been a core value of Crossrail since its inception. In 2009, Crossrail implemented its 'Target Zero' campaign, which has served as the fulcrum of a comprehensive health and safety management system that all industry partners, contractors and supply chain adhered to (Figure 3). Target Zero prescribed the following three basic principles.

- We all have the right to go home unharmed every day.

- We believe that all harm is preventable.

- We must all work together to achieve this.

Target Zero defined the pillars of a successful health and safety management programme by which each contractor's own health and management system was judged using both leading and trailing indicators. 'Golden rules' were initially established around high-risk activities (e.g. working at height, working on energised systems, digging) but then refocused towards the behavioural aspects of health and safety: respect the basics, assess the risks, check the site, follow site requirements and support each other.

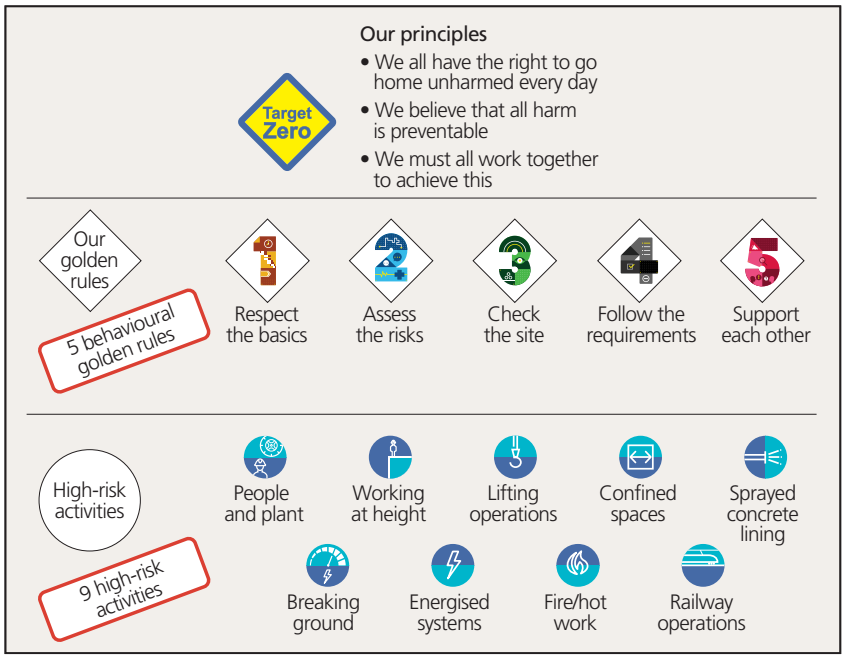

Figure 3. Crossrail's health and safety approach set out three 'Target Zero' principles, five behavioural golden rules and nine high-risk activities

Best practice guides were prepared and published to address key high-risk activities, such as readiness to dig, construction fire safety, operating the tunnel construction railway and use of sprayed concrete lining exclusion zones. These best practice guides can be found on Crossrail's website (www.crossrail.co.uk) and are also available through the project's learning legacy (see learninglegacy. crossrail.co.uk). Supervisor front-line leadership training was offered to all contractor supervision. The Target Zero initiatives were aimed at achieving the project's vision of leaving the construction industry - from the perspective of workplace health and safety - in a better place than when the project started.

Crossrail's vision and values drove how all project participants became engaged in ensuring that how the project was executed was equally as important as the physical railway that was being constructed.

\section{Crossrail's programme}

The Crossrail programme is structured to deliver a series of opening stages as follows.

- Stage 1: progressive introduction of new class 345 rolling stock on existing suburban services between Liverpool Street and Shenfield (May 2017).

- Stage 2: on-network works between Heathrow and Westbourne Park, including services running at a frequency of four trains per hour from Paddington station to Heathrow (May 2018).

- Stage 3: Elizabeth line services running between Paddington low-level and Abbey Wood stations (December 2018).

- Stage 4: through-running of Elizabeth line services between Paddington low-level and both Shenfield and Abbey Wood (May 2019).

- Stage 5: full Elizabeth line service from Reading and Heathrow through the central operating section to Shenfield and Abbey Wood (December 2019). 
The programme for design, procurement, construction and commissioning of the various stages was set in 2009. As of the date of this paper, progress has passed $75 \%$ complete with a high confidence of maintaining and achieving the stagedopening milestones. Figure 4 provides an overview of the project programme.

\section{Overall project management structure}

Crossrail's execution strategy was outlined in the internal document Crossrail Project Delivery Strategy in 2009 and was based on a model in which the overall programme of work would be engineered, procured, constructed and commissioned in a series of projects by Crossrail and its industry partners, third party stakeholders and the supply chain. This was to be accomplished by an integrated delivery team in which Crossrail

- remained responsible for delivery and assurance of the sponsor's requirements

- entered into agreements with Network Rail, London Underground and other third parties as necessary to deliver the programme

- defined the health and safety, environmental and quality regime under which the programme would be delivered

- managed finance and funding

- defined and implemented the strategies for procurement of design, construction and other services to deliver the programme

- integrated the overall programme

- established and managed programme-wide public relations

- coordinated optimal insurance for the programme.

Figure 5 shows the programme management structure.

A programme director was appointed by Crossrail to lead an integrated delivery team made up of Crossrail, programme and project staff and supply chain partners for design, construction and implementation.

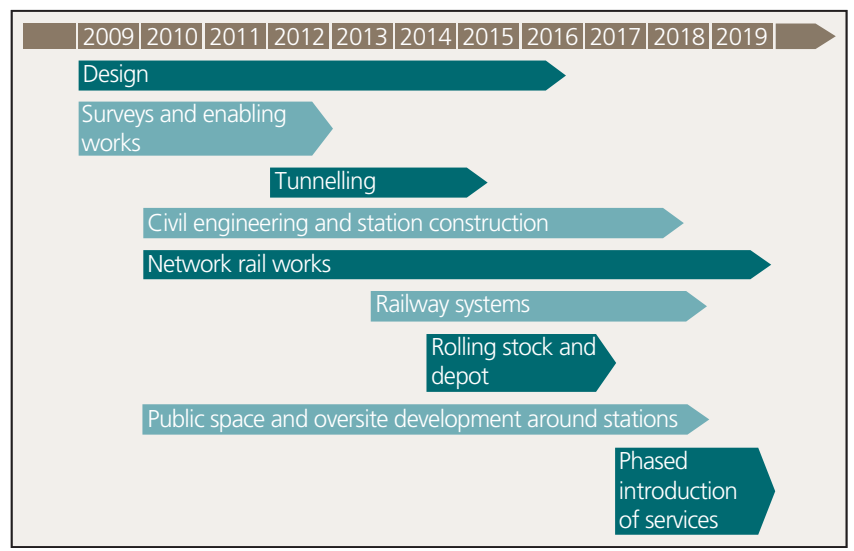

Figure 4. The project's construction programme extends over 10 years - from work starting in May 2009 to full service operation in December 2019
Crossrail secured the services of a programme partner to provide the client team with a professional programme, project and engineering management services and to support the oversight and management of the project at the programme level. This contract was awarded in 2009 to Transcend, a joint venture of CH2M Hill, Aecom and the Nichols Group.

Crossrail secured the services of a project delivery partner to take on the day-to-day responsibility for delivery of the central section and its constituent contracts to time, to the desired quality and within the forecast outturn cost, while fulfilling its obligations under the enabling legislation. This contract was awarded, also in 2009, to Bechtel Ltd and its nominated sub-suppliers Halcrow and Systra. The project delivery organisation is shown in Figure 6.

Agreements were put in place with industry partners for the onnetwork works (Network Rail) and upgrades to the existing London Underground assets (London Underground), Canary Wharf station (Canary Wharf Group) and Woolwich station (Berkeley Homes). Agreements were also put in place with the statutory utilities (Thames Water, British Telecommunications, National Grid, British Gas, etc.) to administer all asset protection and modification works required for existing infrastructure to make way for the new railway.

Crossrail also recognised the need to be able to begin advanced or 'enabling' works before the start of the major central section construction. In 2008, an enabling works management agent contract was awarded to manage the design and implementation for all enabling works, including utility diversions, traffic management, surveys and other protection works. These works were concluded in 2011.

The architecture of this delivery model has remained intact since 2009 and, while the specific organisational delivery structure for the central section has evolved over time during different phases of the project, the basic tenets of Crossrail's vision have stood the test

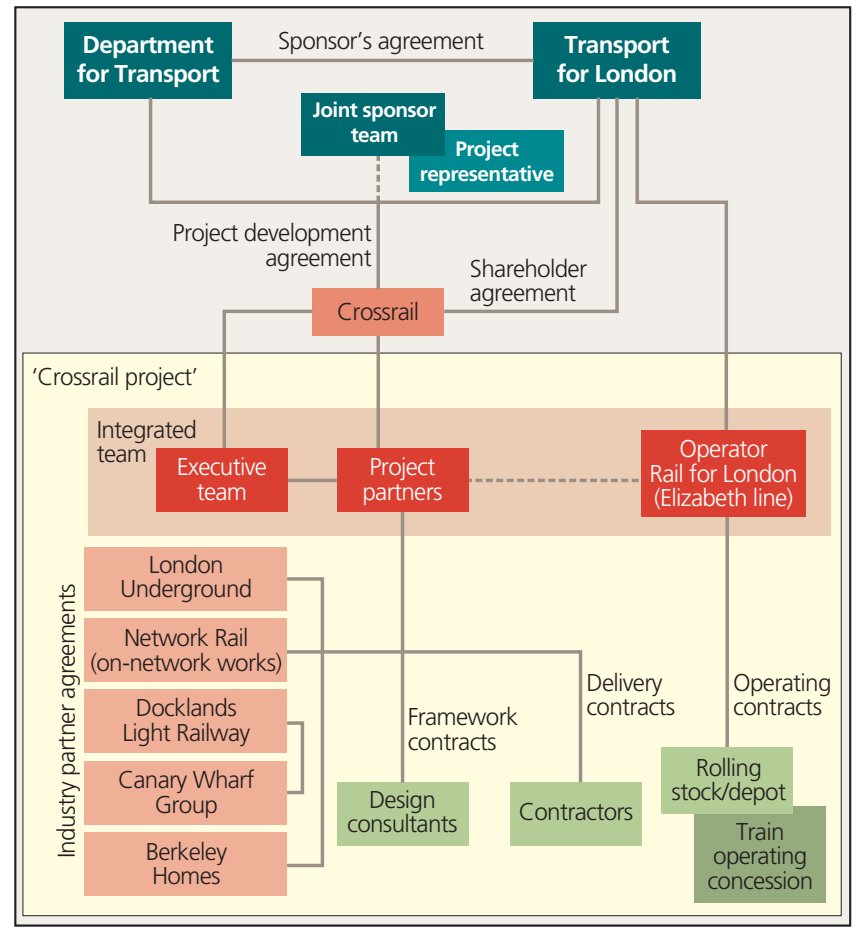

Figure 5. Programme management structure 


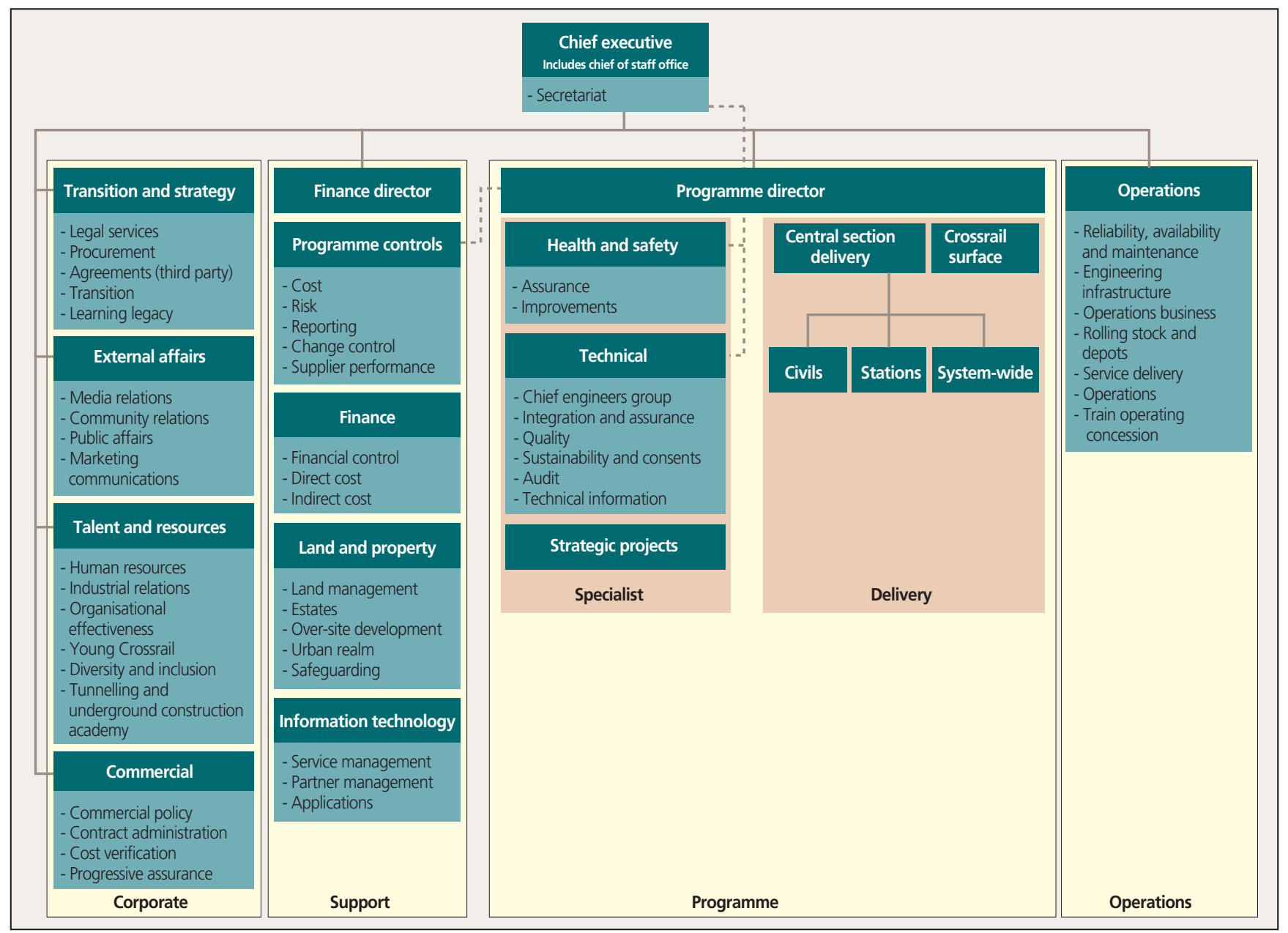

Figure 6. Project delivery organisation

of time. A more detailed examination of how and why the delivery organisation evolved over time will be the focus of a future paper as part of the project's learning legacy.

\section{Design}

The development phase of the Crossrail programme that led up to submission of the hybrid bill in 2008 (Crossrail Act 2008) was supported by three multi-discipline framework designers. They that developed the scheme design to a level of detail broadly synonymous with the Royal Institute of British Architects' (RIBA) Plan of Work stage D (scheme design) and Network Rail's Guide to Rail Investment stage 3 plus in support of the hybrid bill. Their remits aligned with sections of the central section encompassed by the three main bored tunnel drives as depicted in Figure 7.

Once the project was authorised, Crossrail appointed a series of framework design consultants to develop the scheme design of the central section to the level required to establish construction contracts and to manage the design during construction. The civil and structural engineering elements of the design were progressed by the framework design consultants to a level of RIBA stage F as owner-furnished design.

The architectural, electrical, mechanical and rail systems design were progressed by the framework design consultants to a level of RIBA stage E to allow design-build contracts to be let. A detailed procurement strategy was prepared that outlined a number of framework design consultant contracts that would afford the greatest opportunity for the entire supply chain to have the to participate in the detailed design of Crossrail's bored tunnels, sprayed concrete lining tunnels, portals, intermediate shafts, stations, rail systems, communications and controls systems, architectural component design and a common materials and workmanship specification. Table 1 provides a complete listing of all framework design consultant contracts.

The stations were designed as either 'box' structures or 'mined' structures. At Paddington, Canary Wharf and Woolwich, there was sufficient land and the stations were were shallow enough to allow the use of piles to create a cut-and-cover box within which the station was constructed (Figure 8). For the central London locations that included connections to the existing London Underground stations nearby - Bond Street, Tottenham Court Road, Farringdon, 


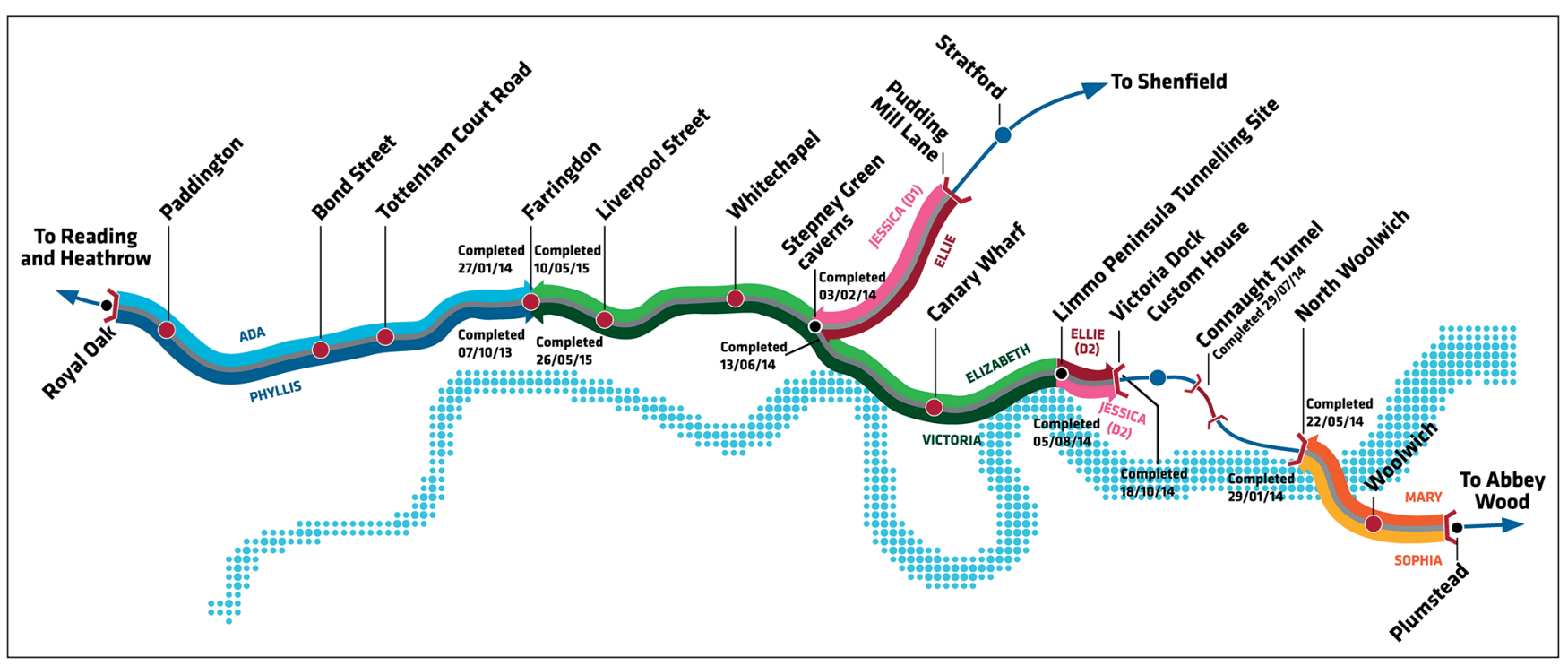

Figure 7. Plan of $21 \mathrm{~km}$ of tunnel drives

\begin{tabular}{|c|c|c|}
\hline $\begin{array}{l}\text { Contract } \\
\text { reference }\end{array}$ & Contract name & Consultant \\
\hline C100 & Common architectural design elements & Atkins \\
\hline C102 & Materials and workmanship & Mott MacDonald \\
\hline C121 & Sprayed concrete lining tunnels & Mott MacDonald \\
\hline C122 & Bored tunnels and track & Arup-Atkins \\
\hline C123 & Intermediate shafts & Jacobs \\
\hline C124 & $\begin{array}{l}\text { Tunnels and shafts aerodynamics and } \\
\text { ventilation }\end{array}$ & Mott MacDonald \\
\hline C125 & Tunnel mechanical and electrical & Mott MacDonald \\
\hline C130 & Paddington station & Scott Wilson \\
\hline C131 & Paddington integrated programme & Mott MacDonald \\
\hline C132 & Bond Street station & WSP \\
\hline C134 & Tottenham Court Road station & Ove Arup and Partners \\
\hline C136 & Farringdon station & Scott Wilson \\
\hline C138 & Liverpool Street station & Mott MacDonald \\
\hline C140 & Whitechapel station & Hyder \\
\hline C146 & Custom House station & Atkins \\
\hline C150 & Royal Oak portal & Capita Symonds Ltd \\
\hline C152 & Pudding Mill Lane portal & Scott Wilson \\
\hline C154 & Victoria Dock portal & Hyder \\
\hline C156 & North Woolwich and Plumstead portals & Capita Symonds Ltd \\
\hline C160 & Rolling stock and depots & Mott MacDonald \\
\hline C162 & $\begin{array}{l}\text { Signalling, traction power, overhead line } \\
\text { equipment and platform screen doors }\end{array}$ & Mott MacDonald \\
\hline C164 & $\begin{array}{l}\text { Bulk power distribution and high- } \\
\text { voltage power }\end{array}$ & Scott Wilson \\
\hline C170 & Communications and control systems & Parsons Brinckerhoff \\
\hline C181 & Westbourne Park advance works & Scott Wilson \\
\hline C183 & Pudding Mill Lane advance works & Mott MacDonald \\
\hline
\end{tabular}

Table 1. Framework design consultant contracts

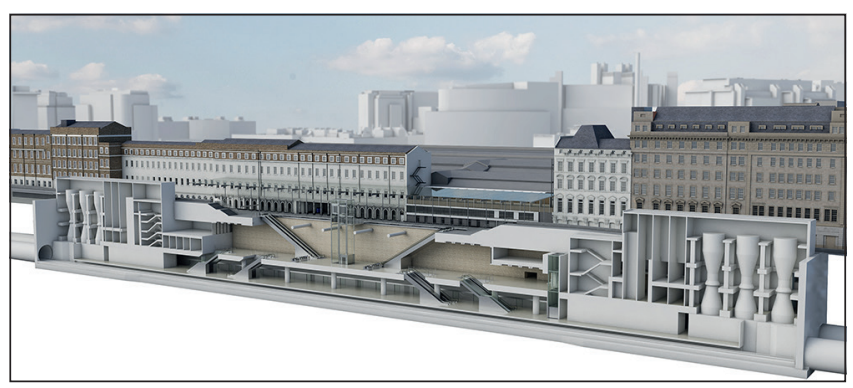

Figure 8. Paddington was a typical cut-and-cover 'box' station

Liverpool Street and Whitechapel - the stations were created using sprayed concrete lining technology (Figure 9).

At Bond Street, Tottenham Court Road and Farringdon, the tunnel boring machines created pilot tunnels leaving sacrificial rings through the length of the station platform which were then mined and enlarged with sprayed concrete lining to create the platform cross-section (Figure 10). At Liverpool Street and Whitechapel, the platform spaces were created before the arrival of the tunnel boring machines using pilot tunnels mined by excavator and sprayed before being enlarged to create the platform cross-section. At these stations, the tunnel boring machines were transported through the platform area before restarting tunnelling from the other end.

Crossrail retained overall responsibility for managing the design and ensuring the integration of the design across all the various interface points. Detailed interface control documents were established that defined the interfaces between each design contract and the other design contracts, and between each design contract and all interfacing construction contracts.

Crossrail also retained overall responsibility for assuring the design and preparing the engineering safety management case that will ultimately demonstrate the safety of the railway to the 
Civil Engineering

Volume 170 Issue CE5
Crossrail project: the execution strategy for delivering London's Elizabeth line

Tucker

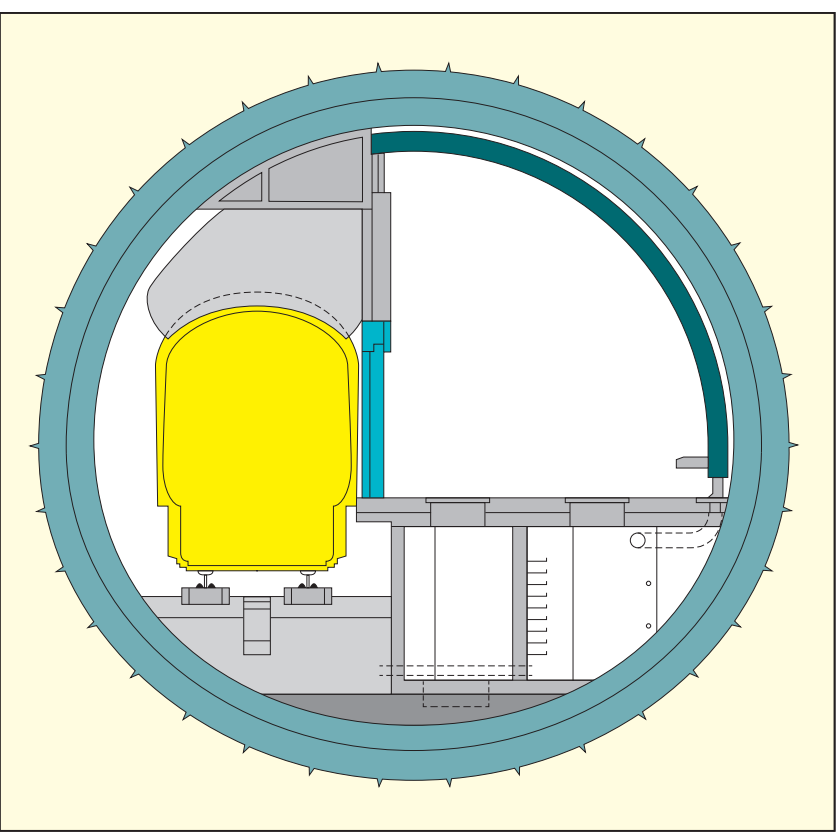

Figure 9. Typical cross-section of a mined station with sprayed concrete lining

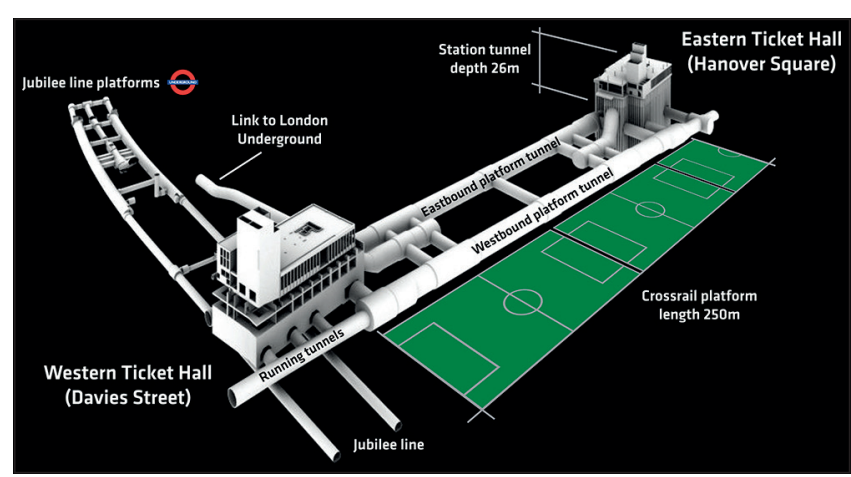

Figure 10. Bond Street is one of the mined stations created after the running tunnels were built - others were mined in advance of the running tunnels

regulators. A technical assurance programme was prepared and issued to document those assurance arrangements and to define the various responsibilities between Crossrail, the supply chain, the infrastructure managers and the operator.

An optimised early contractor involvement process was also developed and implemented to obtain the benefits of the contractors in the finalisation of the detailed design. Upon the award of each tunnelling and station contract, there was a 6 week period of intense interaction between the contractor and designer to review the design for safety, constructability and efficiency. The outcomes of the contractor's reviews of the design then influenced the final design deliverables and the contractor's construction plan.

Crossrail, through its designers, retained overall design responsibility to ensure that all obligations and requirements were incorporated into the final design.

\section{Procurement}

A key component to the overall execution strategy was a robust procurement strategy that was aligned with the vision, values, priorities, constraints, the broader policy environment and procurement best practices in place at the time. Crossrail's role was defined as a utility and, as such, the procurement procedures for contracts above the relevant financial threshold had to comply with the Utilities Contracts Regulations 2006 (HMG, 2006).

The regulations provided for Crossrail to select the use of restricted or negotiated procedures, a pre-qualification of economic operators for tender lists and award of contracts on the most economically advantageous offer from the view of the utility. Best practice principles were established to

- deliver affordable best value

- engage with the supply chain as early as possible

- establish contracts based on a sensible allocation of risk to the party best placed to manage the risk

- incorporate a responsible and sustainable approach to procurement

- establish contractual performance management frameworks

- collaborate with other clients to achieve value and efficiencies.

Crossrail adopted the London mayor's vision for London as an exemplary and sustainable world city and the GLA's policies of delivering strong and diverse economic growth, social inclusivity for all Londoners and fundamental improvements in environmental management and use of resources.

Detailed procurement strategies were prepared and approved to outline the contract packaging and logistics for procurement of the main services in design, advance and enabling works, tunnelling, stations and rail systems that would be managed by the integrated programme management team (Figure 11).

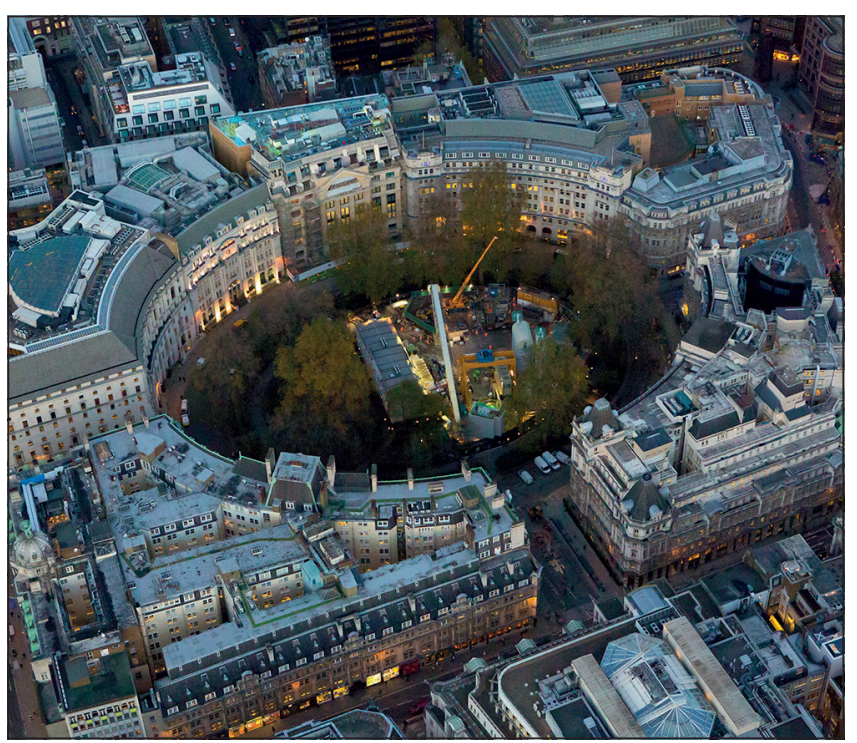

Figure 11. Tunnelling for Liverpool Street station being carried out from Finsbury Circus - detailed procurement strategies were prepared and agreed for all contracts 


\section{Construction and commissioning}

Crossrail elected to use the NEC3 suite of contracts for all of the main delivery contracts and, to a large extent, employed the NEC3 Engineering and Construction Contract (ECC) Option C (target contract with activity schedule). Crossrail retained the responsibility as the employer and delegated the responsibilities of the project manager and supervisor to the integrated programme management team. A complete listing of all construction contracts awarded is given in Table 2 .

The contract structure and geographical nature of the project drove the way in which the integrated programme management team was organised under the execution strategy. A central section delivery director was appointed under the programme director with responsibility to manage delivery of the contracted scopes of work.

As the project progressed, the central section delivery team was organised into sections that supported the particular phase of the project as follows.

- The period 2009-2011 employed three discipline-based directorates: tunnels, portals and shafts, stations and rail systems (system wide).

- The period 2011-2015 employed three geographically based directorates: west, central and east.

- From 2015 to the present, three directorates were employed aligned with the way in which the project will be completed and handed over: stations (Rail for London and London Underground), rail systems (system wide) and civil engineering completion.

The original discipline-based structure was used during the design, procurement and enabling works phases in order to ensure a consistency of requirements and outputs across parallel contracts delivering the same outputs (e.g. a section of bored tunnel). Once major tunnelling commenced, the priorities focused towards managing the complex interfaces between the tunnel drives, the stations, portal and shaft construction and the local authorities and stakeholders that affected those works.
In 2011, the three areas were structured to include all contracts within the geographical limits of the three main bored tunnel contracts. The completion of tunnelling in 2015 marked a major transition of the project from a tunnelling and heavy civil engineering construction focus to a rail systems and station fit-out focus, which needed to be managed in a way that would support the eventual commissioning of a single railway across the entire central section.

The central section delivery team thus again reorganised its leadership to be better aligned to deliver and hand over the final outputs to the various stakeholders who would be involved in the operation and maintenance of the railway: London Underground, Rail for London and the train operating concession.

Upon the award of each construction contract, project teams were formed to manage the contracts under project managers who were delegated as authorised representatives of the project manager. The size of the team was dependent on the size and geographical footprint of the contract they were managing. Certain project teams were responsible for more than one contract when involved in the construction of an individual station.

Each project team comprised dedicated personnel representing contract administration, project controls (cost and scheduling), construction and field engineering. Support staff were assigned to the project teams from central functions for health and safety, environment, quality assurance, risk management and community relations. The previously discussed changes in the management structure of the central section delivery team did not change the fundamental structure of the individual teams at the project level - it simply meant the project manager could be reporting to a different director.

Crossrail strived to employ best practice management and delivery systems in managing the contracts. Traditional project management tools such as a work breakdown structure with associated cost control and financial management, an integrated programme management schedule, commodity-based earned value reporting and a robust trend and change control process were employed. However, Crossrail also strived to motivate contractors to go beyond basic compliance in their reporting,

\begin{tabular}{|c|c|c|c|c|}
\hline $\begin{array}{l}\text { Contract } \\
\text { reference }\end{array}$ & Type $^{\mathrm{a}}$ & $\begin{array}{l}\text { ECC } \\
\text { option }\end{array}$ & Contract name & Contractor \\
\hline C200 & $\mathrm{E}$ & A & Pudding Mill Lane site facilities & Bam Nuttall \\
\hline C201 & E & A & Royal Oak portal taxi facility (demolition advance works) & Keltbray \\
\hline C203 & $\mathrm{E}$ & A & Pudding Mill Lane portal (demolition advanced works) & Laing O'Rourke \\
\hline C207 & E & A & Bond Street demolition for eastern and western ticket hall sites & McGee \\
\hline C208 & $\mathrm{E}$ & A & Tottenham Court Road station demolition for western ticket hall and Fisher Street & McGee \\
\hline C209 & $\mathrm{E}$ & A & Farringdon demolition for eastern ticket hall site & Keltbray \\
\hline C210 & $\mathrm{E}$ & A & Liverpool Street station (civils advance works package 2) & J Murphy \\
\hline C212 & $\mathrm{E}$ & A & Liverpool Street station (demolition advance works) combined & John F Hunt \\
\hline C213 & $\mathrm{E}$ & A & Liverpool Street - signalling correlation works & Sims \\
\hline C214 & $\mathrm{E}$ & A & Liverpool Street - electrical mechanical and plumbing correlation works & RGB \\
\hline C215 & E & A & Liverpool Street - identification of cable and rail utilities & RGB \\
\hline C216 & $\mathrm{E}$ & C & Liverpool Street station (civil advance works - utilities combined services) & Laing O'Rourke \\
\hline C217 & $\mathrm{E}$ & A & Whitechapel station - civils 2 (rail, civils and utilities) & Carillion \\
\hline C220 & $\mathrm{E}$ & A & Old Oak Common site facilities & Laing O'Rourke \\
\hline C223 & $\mathrm{E}$ & A & Bond Street - site facilities & Laing O'Rourke \\
\hline C225 & E & A & Liverpool Street station (site facilities) & Laing O’Rourke \\
\hline C230 & E & A & Westbourne Park (site facilities, demolition and civils) & Morgan Sindall \\
\hline C233 & $\mathrm{E}$ & A & North Woolwich and Victoria Dock (civil advance works - utilities combined services) & J Murphy \\
\hline
\end{tabular}

Table 2. Construction contracts (continued on next page) 


\begin{tabular}{|c|c|c|c|c|}
\hline $\begin{array}{l}\text { Contract } \\
\text { reference }\end{array}$ & Type $^{\mathrm{a}}$ & $\begin{array}{l}\text { ECC } \\
\text { option }\end{array}$ & Contract name & Contractor \\
\hline C240 & E & A & Bond Street (utilities and enabling works) & McNicholas \\
\hline C244 & $\mathrm{E}$ & $\mathrm{E}$ & Whitechapel station - civils 1 (steel deck over East London line) (changed from C244a) & Kier \\
\hline C245 & $\mathrm{E}$ & A & Whitechapel station civils, demolition and utilities around Swanlea School & J Murphy \\
\hline C248 & E & C & Pudding Mill Lane portal (civils, tunnel boring machine reception chamber and $400 \mathrm{kV}$ cable) & Costain-Skanska JV \\
\hline C251 & E & A & Paddington station (public utility diversions) inside Eastbourne Terrace & Laing O'Rourke \\
\hline C252 & E & A & Limmo Peninsula intermediate pressure gas main diversion & McNicholas \\
\hline C254 & A & & Archaeology combined - west & Oxford Archaeological Unit \\
\hline C257 & A & & Archaeology combined - central & Molas \\
\hline C261 & A & & Archaeology combined - early east & Molas \\
\hline C263 & A & & Archaeology combined - late east & Molas \\
\hline C271 & E & A & Paddington integration pre-blockade demolition and groundworks & Carillion \\
\hline $\mathrm{C} 272$ & C & C & Paddington integration - main works (including mechanical and electrical) & Carillion \\
\hline C277 & E & A & Old Oak Common depot demolition & Keltbray \\
\hline C280 & E & C & Old Oak Common - temporary bus facilities & Balfour Beatty \\
\hline C298 & $\mathrm{E}$ & A & Plumstead sidings enabling works & Balfour Beatty \\
\hline C300 & T & C & $\begin{array}{l}\text { Western running tunnels and Bond Street-Tottenham Court Road (early access shafts and sprayed } \\
\text { concrete lining works) }\end{array}$ & BFK Joint Venture \\
\hline C305 & T & C & Eastern running tunnels & Dragados John Sisk \\
\hline C310 & T & C & Drive $\mathrm{H}$ (Thames tunnel) including north Woolwich and Plumstead portals & Hochtief Murphey JV \\
\hline C315 & T & C & Connaught tunnel refurbishment and surface rail works & Vinci \\
\hline C330 & C & C & Royal Oak portal (advanced civils) - phase 1 & Costain-Skanska JV \\
\hline C336 & C & C & Paddington new yard project & Costain \\
\hline C338 & C & A & Paddington new yard batching plant replacement mechanical and electrical works & Liebherr \\
\hline C339 & C & A & Paddington new yard rail discharge system & LJH \\
\hline C340 & T & C & Victoria Dock portal (civil works) & Vinci \\
\hline C350 & $\mathrm{T}$ & C & Pudding Mill Lane portal (main civils works) & Morgan Sindall \\
\hline C360 & C & C & Intermediate shafts finishing works & Costain Skanska JV \\
\hline C405 & C & C & Paddington station (main station works, fit-out and mechanical and electrical) & Costain Skanska JV \\
\hline C411 & C & C & Bond Street station (piling and diaphragm walling) & Costain Skanska JV \\
\hline C412 & C & C & Bond Street station (main station works, fit-out and mechanical and electrical) & Costain Skanska JV \\
\hline C421 & C & C & Tottenham Court Road (piling and diaphragm walling) & BBMV JV \\
\hline C422 & C & C & Tottenham Court Road (main station works, fit-out and mechanical and electrical) & Laing O'Rourke \\
\hline C430 & C & C & Farringdon station (shaft piling and diaphragm walling) & Laing O'Rourke Strabag JV \\
\hline C435 & C & C & Farringdon station (main station works, tunnels, fit-out and mechanical and electrical) & BFK JV \\
\hline C501 & C & C & Liverpool Street station (piling and diaphragm walling) & Bam Nuttall Kier \\
\hline C502 & C & C & Liverpool Street station (main station works, fit-out and mechanical and electrical) & Laing O'Rourke \\
\hline C503 & C & C & Liverpool Street station (civils advance works package 1) & Vinci \\
\hline C510 & C & C & Liverpool Street and Whitechapel station (early access shafts and sprayed concrete lining works) & BBMV JV \\
\hline C511 & C & C & Whitechapel station (piling and diaphragm walling) & Bam Nuttall Kier JV \\
\hline C512 & C & C & Whitechapel station (main station works, fit-out and mechanical and electrical) & BMV JV \\
\hline C520 & C & C & Custom house (main station works) & Laing O'Rourke \\
\hline C530 & C & & Plumstead and Woolwich fit-outs & Balfour Beatty \\
\hline C610 & S & C & Track, overhead line equipment and logistics & ATC JV \\
\hline C620 & $S$ & C & Railway signalling and control (central operating section) & Siemens Invensys JV \\
\hline C631 & $S$ & & Platform screen doors & Knorr Bremse \\
\hline C644 & S & C & Central section traction power infrastructure & Alstom Costain JV \\
\hline C650 & $\mathrm{s}$ & $\mathrm{C}$ & Non-traction high-voltage power & Alstom Costain JV \\
\hline C660 & S & C & Communications and controls systems & Siemens \\
\hline C701 & M & B & Instrumentation and monitoring & ITM \\
\hline C704 & M & B & Instrumentation and monitoring & Soldata \\
\hline C730 & S & Other & Pan-TfL lift agreement & Kone \\
\hline C740 & S & Other & Escalators & Otis \\
\hline $\mathrm{C} 803$ & A & & Traffic signage & Ringway Jacobs \\
\hline C806 & C & A & Wallasea temporary jetty & Bam Nuttall \\
\hline C807 & M & B & Marine transportation & Bam Nuttall Van Oord JV \\
\hline C809 & A & & Noise insulation & Anglian Windows \\
\hline C815 & $M$ & A & Tunnelling academy & VolkerFitzpatrick \\
\hline $\mathrm{C} 828$ & $C$ & C & Ilford yard stabling sidings & VolkerFitzpatrick \\
\hline
\end{tabular}


and implemented a number of new measures to evaluate the contractors' performance and stimulate their continued improvement.

- 'Gateway' was established to measure systematically the contractors' performance against the Target Zero health and safety objectives. Criteria were set against the six Target Zero pillars (leadership, communication, design for health and safety, workplace safety, workplace health and continuous improvement). The Health and Safety performance of Crossrail is the subject of a learning legacy paper (Crofts, 2016).

- A 'Green Line award' was established to recognise contractors that were exceeding both Crossrail and industry expectations with respect to their management of the environment and their engagement with local communities. The Green Line award is explained further in a learning legacy paper (Mellings and Myatt, 2016).

- 'Performance assurance' was established to provide an independent measure of the contractors' compliance with contract requirements in the key areas of delivery (e.g. health and safety, quality, environment, responsible procurement, contract administration). The performance assurance process relied on inputs from other processes, such as gateway, and became the summary 'report card' on contractor performance. The evaluations resulted in scores of 1.0 to 3.0 , with 1.0 representing basic compliance with contractual requirements, $2 \cdot 0$ representing compliance above the basic contract requirements and 3.0 representing a contractor exhibiting world-class performance (e.g. industry best practice). Over time, contractors were consistently able to achieve average scores above $2 \cdot 0$. The positive effect of a contractor publicly seeing where they stood in relation to their peers proved to be a positive motivational tool to improve performance. The performance assurance programme is the subject of a separate Crossrail learning legacy paper (Wood, 2016).

- 'Innovate 18' was a programme designed to motivate contractors to be innovative in their management of the work and provided a forum for the pursuit and sharing of ways in which to improve delivery. A number of interesting and relevant innovations from Crossrail can be found at the new Infrastructure Industry Innovation portal (www.i3p.org.uk).

Planning of the works, and adherence to the plan, was a fundamental principle of managing the contracts. As tunnelling was completed on the project (Figure 12), a master operational handover schedule was employed to focus the integrated programme into testing, commissioning and handover. ' 100 day plans' were implemented to help deliver critical handover schedule milestones or to integrate multiple-contractor interfaces to achieve complex milestones involving many contractors. Readiness reviews were implemented before allowing contractors to proceed into new areas of work such as digging, tunnelling, sprayed concrete lining work, testing and commissioning.

Sound contract management principles were used to ensure the timely and fair administration of the NEC3 contracts. Crossrail retained the responsibilities of the employer and remained active in the day-to-day understanding of each contract's status and issues while allowing the project manager to objectively administer the contract. A dispute resolution process was built into the contract

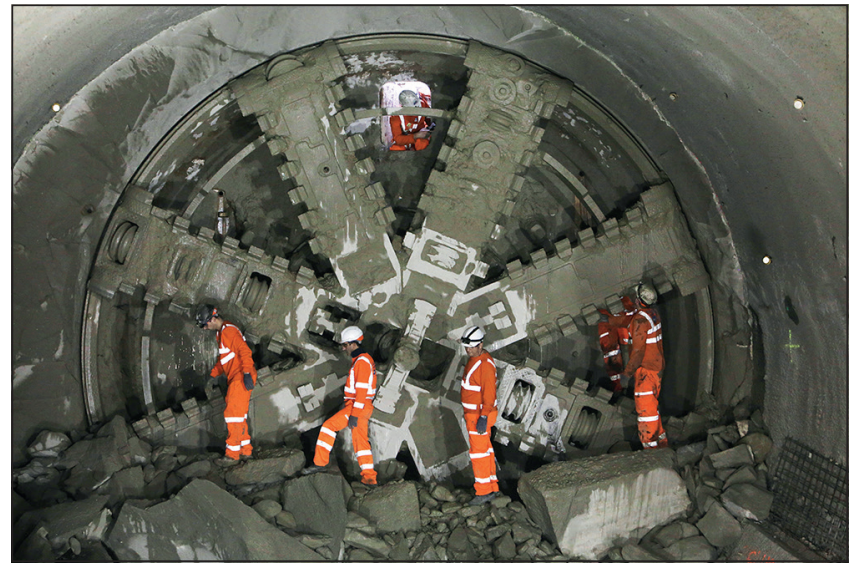

Figure 12. Tunnelling was completed in June 2015, moving the project into a major handover phase

where matters could be raised for managerial discussions prior to being referred to adjudication.

A number of collaborative and leading-edge processes were used to administer the contracts in a collaborative manner. A project-wide all-risk insurance policy was procured by Crossrail and extended to each of the construction contracts. Project bank accounts were established for each contract and used to monitor contractors' compliance with fair payment legislation to their supply chain. An employer's completion process was developed and implemented for every contract to ensure all aspects of the contract requirements were satisfied and contract deliverables accepted before the contract could be closed.

A community relations strategy was developed, as mandated by the Crossrail construction code. As such, the strategy was in and of itself a parliamentary undertaking and binding on all parties. The strategy reflected how Crossrail would satisfy the requirements of all its parliamentary undertakings, manage local community relations, engage with local authorities and other key stakeholders, disseminate information and be a positive influence in the community through sustainability and responsible procurement initiatives. These requirements were passed down to each contractor under the contract who worked under a framework managed through dedicated community relations officers.

Specific community engagement plans were prepared to identify how relations would be managed with each local authority. The robust management of community relations at the borough and citizenry levels was essential for Crossrail to maintain its 'licence to operate' through its powers and permissions granted by the local authorities.

The project was the first of its scale in the UK to consider social, economic and environment sustainability in its decision-making from day one. The execution strategy and implementing procedures drove these decisions through design, procurement, construction and commissioning to minimise the impacts of the project and to maximise benefits. The commitment to working with a diverse supply chain to source materials used on the project ethically was translated into the construction contract documents to help drive improvements in safety, skills, learning and expertise to hand over to the next generation of projects. 
Civil Engineering

Volume 170 Issue CE5
Crossrail project: the execution strategy for delivering London's Elizabeth line

Tucker

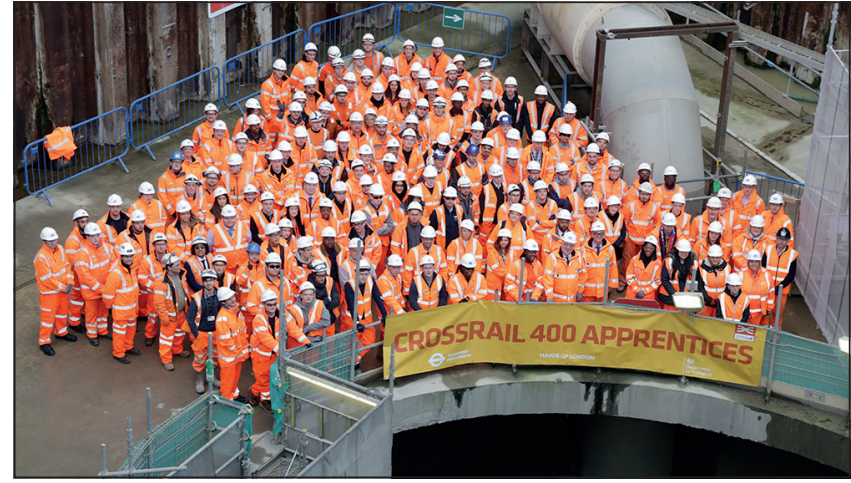

Figure 13. Over 500 apprentices were hired on the project

As a result, over 500 apprentices were hired (Figure 13), over 10000 people were trained in the tunnelling and underground construction academy, over 10000 heavy goods vehicle drivers were trained to new and higher driver safety standards, over 1000 young people undertook work experience opportunities and over 4000 job starts were provided to local or previously unemployed people. Around $95 \%$ of Crossrail contracts were awarded to companies within the UK and $61 \%$ of UK suppliers were based outside London.

Over $6 \mathrm{Mt}$ of excavated material was handled, $98 \%$ of which was beneficially reused, including $3 \mathrm{Mt}$ used to create a new bird sanctuary for the RSPB reserve at Wallasea Island in Essex (Figure 14).

The staged introduction of services revolves around the opening of the central operating section in December 2018. To build additional float and certainty on that stage, an effort was realised to plan for commencing early dynamic testing of a portion of the route (between Plumstead and Canary Wharf) in November 2017. This provided a 2 month additional float to the overall commissioning scheme. Detailed testing and commissioning schedules are being developed to support early dynamic testing and to integrate the activities of the various contractors into a single programme for the end-to-end railway.

\section{Transition into operations}

The completion and handover of the Crossrail project will be a complex undertaking. Rail for London will take overall responsibility for the central section assets. Individual stations, portals and shafts will be handed over to either London Underground or Rail for London as the infrastructure manager.

Upon completion of dynamic testing (Figure 15), the railway will enter into trial operations under the jurisdiction of Rail for London and the train operating concession. To support that, a comprehensive programme of handover, asset data transfer and training is being developed. Crossrail, through its contractors, is obliged to 'train the trainers' so the operators and infrastructure managers can then train their staff in advance of trial operations.

Crossrail appointed its operations director in 2011, who established a team of operations, maintenance and planning staff whose responsibility was to prepare for trial operations, manage

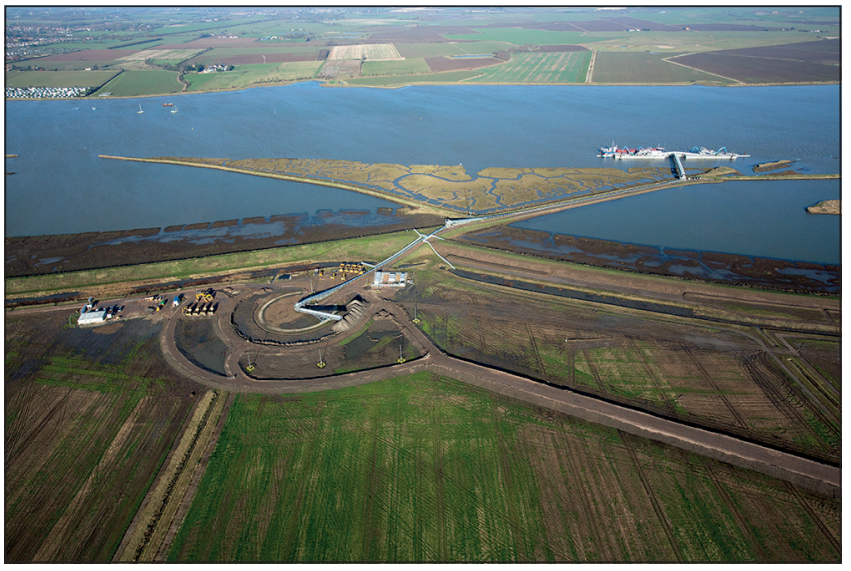

Figure 14. Half the $6 \mathrm{Mt}$ excavated material was used to create the Jubilee Marsh habitat creation project in Essex and part of the RSPB Wallasea Island Wild Coast Project - most of the rest was also beneficially reused

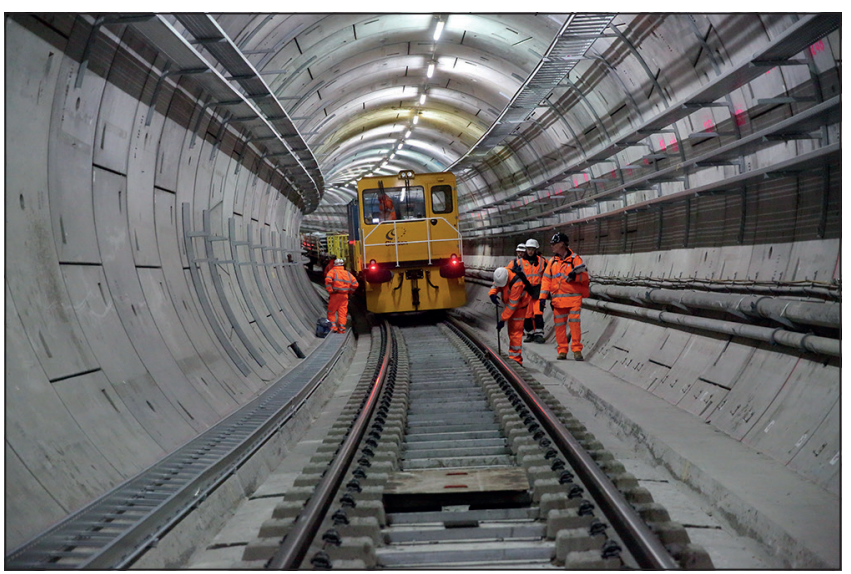

Figure 15. Rail systems installation in the running tunnels is part of the system-wide works

delivery of the rolling stock and the main depot at Old Oak Common, manage and administer the train operator contract and, importantly, interface with the delivery team during design and construction of the assets they would ultimately be responsible for.

A greater examination of the way in which the assets were commissioned, brought into use and handed over to the infrastructure managers will be the subject of a separate paper(s).

\section{Crossrail's learning legacy}

In keeping with the Crossrail vision and values, Crossrail has committed to establishing a learning legacy that aims to be a collation and dissemination of good practice, lessons learned and innovation from the Crossrail construction programme.

Case studies and technical papers are being prepared under a variety of themes, including project and programme management, health and safety, talent and resources, environment, operations and innovation. 
A series of learning legacy events continues to be developed with Crossrail's learning legacy partners. Access to Crossrail's learning legacy can be found at learninglegacy.crossrail.co.uk.

\section{Conclusions}

As of the date of this paper, the programme is more than $75 \%$ complete with all bored tunnelling complete and rail systems installation having commenced (Figure 16). The project is now focusing towards systems installation, testing, commissioning and handover. The basic principles envisioned in 2008 remain the basis for Crossrail's execution model to this day. A number of conclusions can be drawn that, in turn, would stand as lessons learned or recommendations for future major infrastructure projects.

It is essential that adequate time be provided to think through a detailed execution strategy before a robust plan or programme can be developed for a project.

A client should reasonably assess its own competencies and capacities to understand how to leverage the use of strategic partners and its supply chain in an execution strategy.

The execution strategy must consider the full lifecycle of the project to ensure it is robust enough to accommodate the changes in priorities that come with the changing phases of a project over a long period of time.

The greater the sub-divisions in the scope of a project, the more interfaces are created that the client needs to manage. A robust interface management and control procedure must be developed and issued before any procurement begins under the execution strategy.

The importance of the client having a clear vision and set of values that drive behaviours and decision-making cannot be underestimated. All activities and the measurement of a project's success over the lifecycle of the project must remain tied to that vision and values.

The goals and objectives of the client must be clearly cascaded through the contracts and aligned down the entire supply chain. A robust analysis of the supply chain's performance against those goals and objectives must be implemented. The use of competition among the supply chain will result in improvements in overall performance.

The detailed identification of how a complex project will be tested, commissioned and handed over must be accomplished as early as possible and used as a basis for developing the overall execution strategy and project delivery schedule. Engagement of the end users and other stakeholders in this process is essential.

The greater the level of design completion, including the full satisfaction of all interface requirements between various designers and third parties, that can be achieved before procurement of construction contracts, the better chance there is of avoiding change and conflict during implementation.

Crossrail's success to date has been, in part, due to equal emphasis on 'how' the project is being delivered and 'what' is being delivered (Figure 17). To this end, the Crossrail learning legacy will sponsor this and other technical papers that will be documenting the best practice and lessons learned from Crossrail for the benefit of the industry's future use.

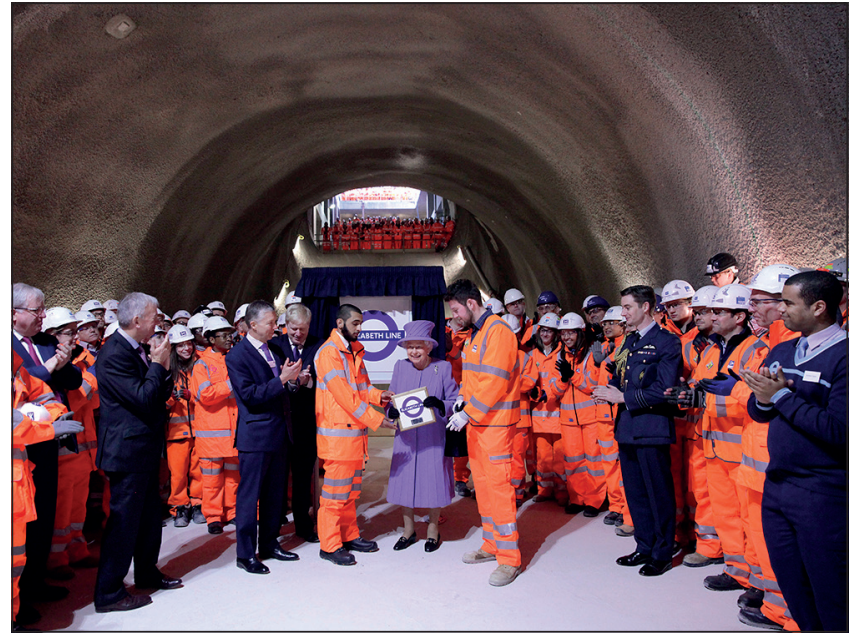

Figure 16. Queen Elizabeth unveiling the Elizabeth line at Bond Street station in February 2016

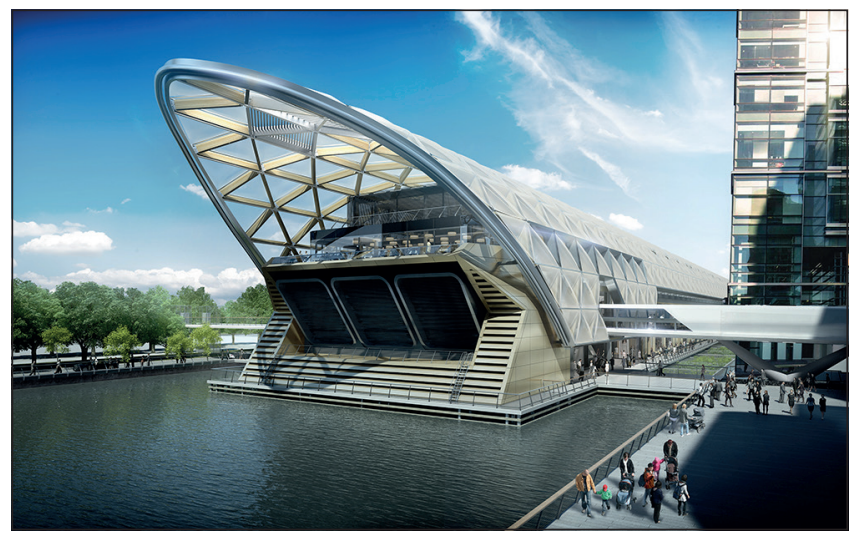

Figure 17. How Canary Wharf station will look when the Elizabeth line opens in 2018

\section{References}

Crofts S (2016) Health and Safety Performance Index (HSPI). Crossrail Learning Legacy. See http://learninglegacy.crossrail.co.uk/documents/hspi/ (accessed 28/11/2016).

Crossrail Act 2008. Chapter 18. Her Majesty's Stationery Office, London, UK.

HMG (Her Majesty's Government) (2006) Public Procurement, England and Wales, Public Procurement, Northern Ireland. The Utilities Contracts Regulations 2006. The Stationery Office, London, UK, Statutory Instrument 2006 No. 6.

Mellings L and Myatt C (2016) Promoting Positive Environmental Behaviour Change at Crossrail - Lessons Learned from Implementing the Green Line Recognition Scheme. Crossrail Learning Legacy. See http://learninglegacy. crossrail.co.uk/documents/lessons-learned-green-line-scheme/ (accessed 28/11/2016).

Wood R (2016) Performance Assurance Framework. Crossrail Learning Legacy. See http://learninglegacy.crossrail.co.uk/documents/performanceassurance-overview/ (accessed 28/11/2016). 